\title{
Exlibris Biblioteka Gerontologii Społecznej
}

\author{
Abstrakt \\ Krótka informacja o czasopiśmie. \\ Słowa kluczowe: czasopismo gerontologiczne. \\ Exlibris Social Gerontology Library
}

\begin{abstract}
Brief information on the journal.
\end{abstract}

Keywords: gerontological journal.

EXLIBRIS Biblioteka Gerontologii Społecznej jest czasopismem stworzonym z myślą o wymianie doniesień naukowych szerokiego grona polskich i zagranicznych badaczy. Inicjatorem uruchomienia czasopisma o tematyce gerontologicznej był Artur Fabiś. Od samego początku do pierwszych prac organizacyjnych, a później redakcyjnych i edytorskich włączyły się także znane szerokiemu gronu gerontologów społecznych reprezentantki dwóch ważnych ośrodków badawczych: łódzkiego - prof. Elżbieta Dubas, która objęła funkcję Redaktor Naczelnej, oraz krakowskiego - prof. Zofia Szarota. W zamierzeniach periodyk skierowany był do naukowców, wykładowców, praktyków, studentów, a także do osób zainteresowanych poszerzaniem swej wiedzy w obszarze gerontologii społecznej, edukacyjnej i opiekuńczej. Z czasopismem współpracowało i nadal współpracuje grono wybitnych uczonych, pełniąc rolę członków rady naukowej oraz recenzentów.

\footnotetext{
* Uniwersytet Pedagogiczny w Krakowie.
} 
Początkowo Biblioteka Gerontologii Społecznej przybrała formę serii wydawniczej, w której prezentowane miały być zbiory artykułów zebranych tematycznie, a zredagowanych przez specjalistów z zakresu szeroko rozumianej gerontologii. Po pierwszych czterech tomach, które koncentrowały się wokół aktywności i społecznych uwarunkowań starzenia się oraz problemowi zależności w starości, serię przekształcono w czasopismo i przeniesiono do Wydawnictwa Naukowego „Śląsk”. Tam też powstały pierwsze 3 numery poruszające głównie tematykę uczenia się w starości. W roku 2014 funkcję Redaktor naczelnej przejęła prof. Zofia Szarota, periodyk zaczął ukazywać się pod auspicjami Uniwersytetu Pedagogicznego w Krakowie, a do nazwy dodano „Exlibris”. Poza stworzeniem nowej szaty graficznej wprowadzono zasadę publikowania $\mathrm{w}$ roku kalendarzowym jednego numeru w językach kongresowych i jednego w języku polskim. Poszerzono zawartość czasopisma o dział kronikarski opisujący ważne wydarzenia polskiej gerontologii społecznej, dział recenzencki i sprawozdawczy, by wszelkie inicjatywy podejmowane w środowisku były trwale zaznaczone. Tak powstało kolejnych osiem numerów czasopisma o bardzo zróżnicowanej tematyce z zakresu: specyfiki uczenia się seniorów w Polsce, duchowości, polityki senioralnej, aspektów zdrowotnych i społecznych, roli osób starszych w rodzinie, różnych modeli starzenia się i przestrzeni fizycznej w starości. Rok 2019 przyniósł kolejne zmiany, funkcję Redaktora Naczelnego przejął dr hab. Artur Fabiś. Powstają kolejne 2 numery o relacjach i specyfice starzenia się w Polsce, a na rok 2020 zaplanowane są dwa następne.

Wersją pierwotną czasopisma jest wydanie papierowe. Czasopismo jest dostępne na stronie internetowej Uniwersytetu Pedagogicznego w Krakowie pod adresem: www.bgs.up.krakow.pl 